\title{
The first total synthesis of lamellarin $\alpha 20$-sulfate, a selective inhibitor of HIV-1 integrase
}

\author{
Tomohiro Yamaguchi, ${ }^{\mathrm{a}}$ Tsutomu Fukuda, ${ }^{\mathrm{a}}$ Fumito Ishibashi, ${ }^{\mathrm{b}}$ and \\ Masatomo Iwao ${ }^{\mathrm{c}, *}$ \\ ${ }^{a}$ Graduate School of Science and Technology, ${ }^{b}$ Division of Marine Life Science and Biochemistry, Faculty \\ of Fisheries, ${ }^{c}$ Department of Applied Chemistry, Faculty of Engineering, Nagasaki University, 1-14 \\ Bunkyo-machi, Nagasaki 852-8521, Japan
}

\begin{abstract}
The first total synthesis of lamellarin $\alpha 20$-sulfate (1), a selective inhibitor of HIV-1 integrase, has been completed. The lamellarin $\alpha$ core in which $13-\mathrm{OH}$ and 20-OH were differentially protected by isopropyl and benzyl groups, respectively, was constructed by using Hinsberg-type pyrrole synthesis and Suzuki-Miyaura coupling as the key reactions. The 20-sulfate was prepared by a sequence including debenzylation of 20-OBn, 2,2,2-trichloroethylsulfation of the resulting 20-OH, deprotection of 13-O $i$-Pr, and final reductive cleavage of the 2,2,2-trichloroethyl ester.
\end{abstract}

Keywords: HIV-1 integrase inhibitor; lamellarin; sulfate; Hinsberg reaction; Suzuki-Miyaura coupling

*Corresponding author. Tel./fax: +81 95819 2681; e-mail:iwao@net.nagasaki-u.ac.jp

Human immunodeficiency virus (HIV) encodes three enzymes, namely, reverse transcriptase, protease, and integrase. Anti-HIV drugs targeting the first two enzymes have been successfully employed for treatment of acquired immune deficiency syndrome (AIDS). Integrase is another attractive and safe target against HIV because it is essential for HIV replication and, unlike reverse transcriptase and protease, there is no similar enzyme in the host cell. ${ }^{1}$ Unfortunately, however, no clinically useful integrase inhibitors have been developed so far.

Lamellarins are polycyclic marine alkaloids having a unique 
14-phenyl-6H-[1]benzopyrano[4',3':4,5]pyrano[2,1-a] isoquinolin-6-one ring-system. ${ }^{2}$ So far, over 30 lamellarins have been isolated from mollusks, tunicates, and sponges. These alkaloids have received considerable attention as new leads for anticancer agents. $^{3} \quad$ In 1999, Faulkner and coworkers discovered a series of lamellarin alkaloids exhibit selective inhibition of HIV-1 integrase. ${ }^{4}$ Within the alkaloids tested, lamellarin $\alpha$ 20-sulfate (1) displayed the most favorable therapeutic index. The sulfate $\mathbf{1}$ inhibited the integrase terminal cleavage activity with an $\mathrm{IC}_{50}$ of $16 \mu \mathrm{M}$, the strand transfer activity with an $\mathrm{IC}_{50}$ of $22 \mu \mathrm{M}$, and growth of the HIV-1 virus in cell culture with an $\mathrm{IC}_{50}$ of $8 \mu \mathrm{M}$. The MTT assay of $\mathbf{1}$ toward Hela cells displayed the least toxicity with an $\mathrm{LD}_{50}$ of $274 \mu \mathrm{M}$. Protection of the phenolic hydroxyl group as the sulfate could reduce the cytotoxicity of the parental lamellarins in general.

A synthetic approach to lamellarin $\alpha$ 20-sulfate (1) was reported by Faulkner and coworkers in 2002. ${ }^{5}$ They prepared lamellarin $\alpha$ (2) using an intramolecular 1,3-dipolar cycloaddition strategy developed by Banwell. ${ }^{6}$ An attempt to synthesize 1 by titration of 2 with a conventional $\mathrm{DMF}-\mathrm{SO}_{3}$ complex failed and afforded only lamellarin $\alpha$ 13,20-disulfate (3) in low yield. Recently, Taylor developed a reliable method to produce aryl sulfates via mixed aryl 2,2,2-trichloroethyl sulfate intermediates. $^{7}$ In this Letter, we report the first total synthesis of lamellarin $\alpha$ 20 -sulfate (1) using Taylor's protocol for the final steps of sulfate formation. ${ }^{8}$

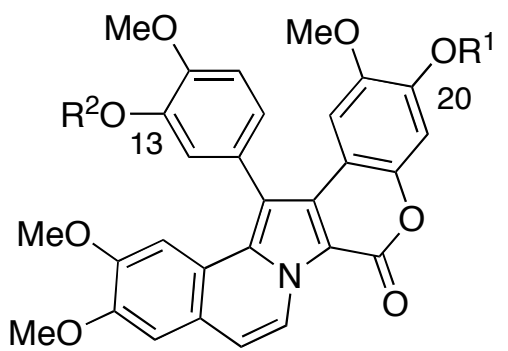

lamellarin $\alpha$ 20-sulfate (1) $\left(\mathrm{R}^{1}=\mathrm{SO}_{3} \mathrm{Na}, \mathrm{R}^{2}=\mathrm{H}\right)$

lamellarin $\alpha(2)\left(R^{1}=R^{2}=H\right)$

lamellarin $\alpha$ 13,20-disulfate (3) $\left(R^{1}=\mathrm{R}^{2}=\mathrm{SO}_{3} \mathrm{Na}\right)$

lamellarin $\alpha$ core $(4)\left(\mathrm{R}^{1}=\mathrm{Bn}, \mathrm{R}^{2}=i-\mathrm{Pr}\right)$

The pivotal lamellarin $\alpha$ core 4 in which $13-\mathrm{OH}$ and $20-\mathrm{OH}$ are differentially protected for the selective introduction of a sulfate group was constructed by a strategy developed 
in our laboratories. ${ }^{9}, 10$ This includes Hinsberg-type pyrrole synthesis ${ }^{11}$ and palladium-catalyzed Suzuki-Miyaura coupling ${ }^{12}$ of the 3,4-dihydroxypyrrole bistriflate as the key reactions. The total synthesis of lamellarin $\alpha 20$-sulfate (1) based upon this strategy is shown in the Scheme.

Alkylation of the commercially available 2-(3,4-dimethoxyphenyl)ethylamine (5) with 2.2 equiv. of methyl bromoacetate gave the iminodiacetate 6 in $91 \%$ yield. Hinsberg reaction of 6 with dimethyl oxalate under the conventional $\mathrm{NaOMe} / \mathrm{MeOH}$ condtions ${ }^{9,11}$ provided 3,4-dihydroxypyrrole 7 in only $49 \%$ yield. However, the yield was greatly improved to $85 \%$ by carrying out the reaction in dry THF using sodium hydride as a base. ${ }^{10}$ Reaction of 7 with 2.0 equiv. of trifluoromethanesulfonic anhydride in pyridine gave the corresponding bistriflate derivative $\mathbf{8}$ in good yield. The bistriflate $\mathbf{8}$ was coupled with 1.0 equiv. of the boronic acid $9^{10}$ in the presence of $2 \mathrm{~mol} \%$ of $\mathrm{Pd}\left(\mathrm{PPh}_{3}\right)_{4}$ and aqueous $\mathrm{Na}_{2} \mathrm{CO}_{3}$ in refluxing THF to give the mono-arylated pyrrole $\mathbf{1 0}$ in $80 \%$ yield. The second cross-coupling of this product with 2.0 equiv. of $\mathbf{1 1}^{13}$ using $8 \mathrm{~mol} \%$ of $\mathrm{Pd}\left(\mathrm{PPh}_{3}\right)_{4}$ produced 3,4-disubstituted pyrrole 12 in $90 \%$ yield. Deprotection of the MOM group of $\mathbf{1 2}$ with $\mathrm{HCl}$ in methanol caused concomitant lactonization to give $\mathbf{1 3}$ in 93\% yield. Alkaline hydrolysis of $\mathbf{1 3}$ followed by treatment with $p$-TsOH in refluxing dichloromethane gave the acid $\mathbf{1 4}$ in $\mathbf{7 7 \%}$ yield. Decarboxylation of this compound in hot quinoline in the presence of $\mathrm{Cu}_{2} \mathrm{O}$ provided 15 in $96 \%$ yield. ${ }^{14}$ Intramolecular oxidative biaryl coupling of $\mathbf{1 5}$ under Kita's conditions ${ }^{15}$ [phenyliodine bis(trifluoroacetate) (PIFA) $\left./ \mathrm{BF}_{3} \mathrm{Et}_{2} \mathrm{O}\right]$ proceeded cleanly to produce the cyclized compound $\mathbf{1 6}$ in $95 \%$ yield. Dehydrogenation of this compound with 2,3-dichloro-5,6-dicyano-1,4-benzoquinone (DDQ) gave 20-benzyl-13-isopropyllamellarin $\alpha$ (4) in 99\% yield. Deprotection of the benzyl group by hydrogenolysis over palladium on charcoal afforded 17, which was reacted with trichloroethyl chlorosulfate in pyridine to give the mixed sulfate $\mathbf{1 8}$ in $96 \%$ yield. $^{6}$ Selective removal of the isopropyl protecting group of $\mathbf{1 8}$ with boron trichloride ${ }^{16}$ proceeded cleanly without affecting the trichloroethylsulfate moiety to give 19 in $96 \%$ yield. Final reductive deprotection of the trichloroethyl ester with $\mathrm{Zn} / \mathrm{HCO}_{2} \mathrm{NH}_{4}$ followed by ion exchange over Amberlite IRC-50 ( $\mathrm{Na}^{+}$form) and Sephadex purification produced lamellarin $\alpha 20$-sulfate (1) in $80 \%$ yield. 

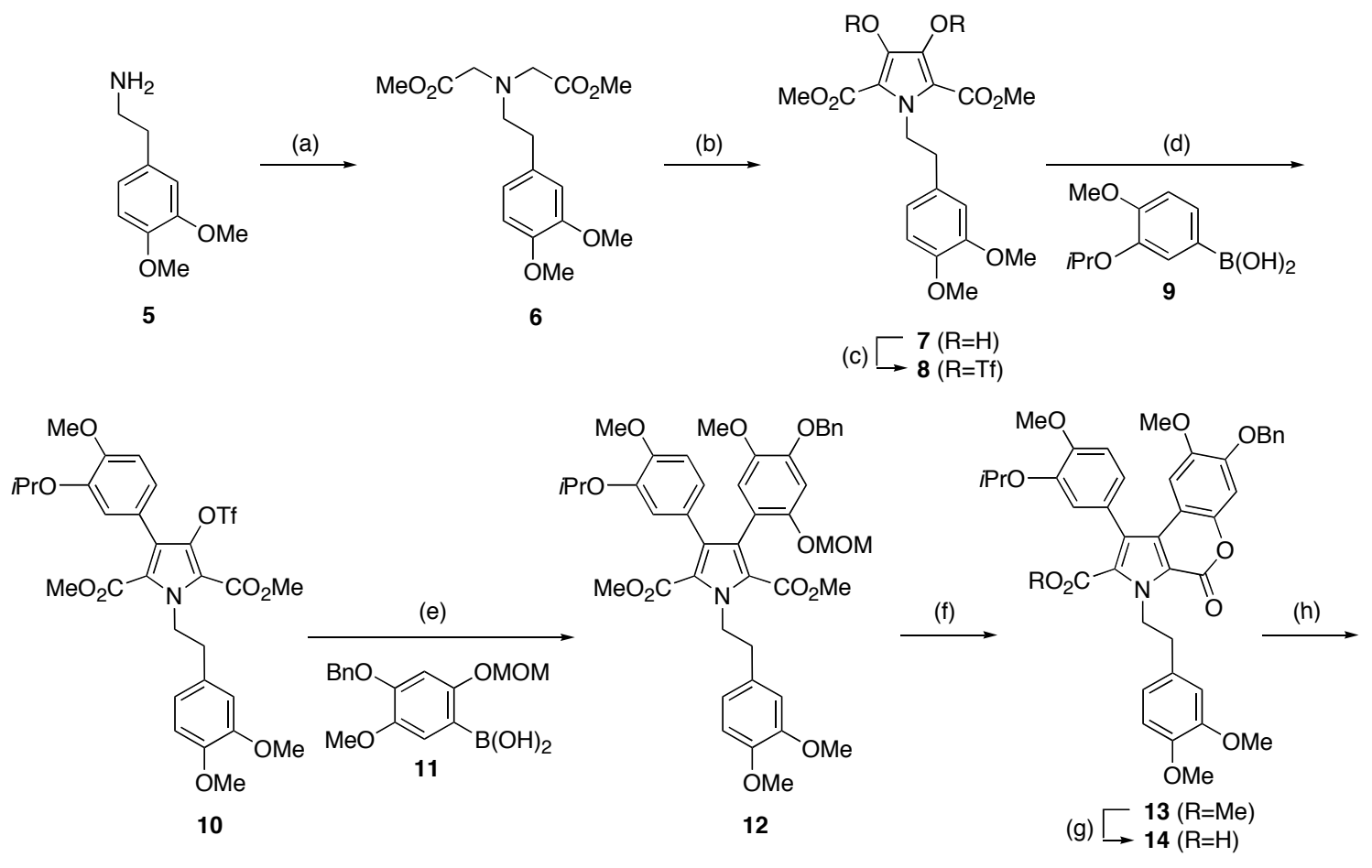

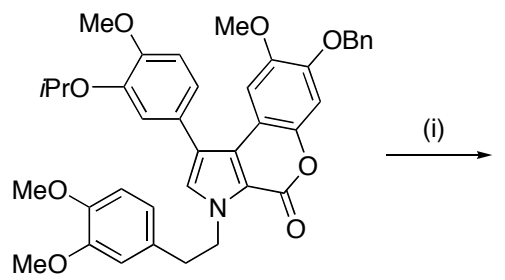

15

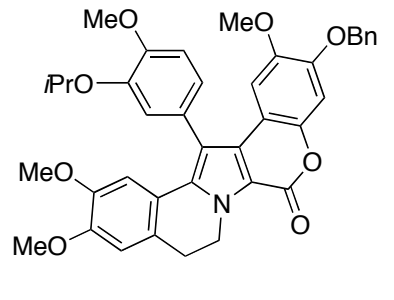

16

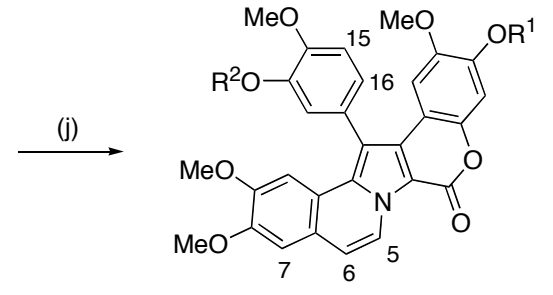

(k) $\quad 4\left(\mathrm{R}^{1}=\mathrm{Bn}, \mathrm{R}^{2}=\mathrm{Pr}\right)$

$\Rightarrow 17\left(\mathrm{R}^{1}=\mathrm{H}, \mathrm{R}^{2}=\mathrm{Pr}\right)$

$(\mathrm{l}) \rightarrow 18\left(\mathrm{R}^{1}=\mathrm{SO}_{3} \mathrm{CH}_{2} \mathrm{CCl}_{3}, \mathrm{R}^{2}=\mathrm{Pr}\right)$

$(\mathrm{m}) \underset{\mathrm{C}}{\longrightarrow} \mathrm{19}\left(\mathrm{R}^{1}=\mathrm{SO}_{3} \mathrm{CH}_{2} \mathrm{CCl}_{3}, \mathrm{R}^{2}=\mathrm{H}\right)$

(n) $\rightarrow 1\left(\mathrm{R}^{1}=\mathrm{SO}_{3} \mathrm{Na}, \mathrm{R}^{2}=\mathrm{H}\right)$

Scheme. Total synthesis of lamellarin $\alpha$ 20-sulfate (1). Reagents and conditions: (a) $\mathrm{BrCH}_{2} \mathrm{CO}_{2} \mathrm{Me}$ (2.2 equiv.), $\mathrm{NaHCO}_{3}, \mathrm{CH}_{3} \mathrm{CN}$, reflux, 2.5 h (91\%); (b) $\left(\mathrm{CO}_{2} \mathrm{Me}\right)_{2}$ (2.0 equiv.), $\mathrm{NaH}$ (4.0 equiv.), THF, reflux, 4.5 h (85\%); (c) $\left(\mathrm{CF}_{3} \mathrm{SO}_{2}\right)_{2} \mathrm{O}$ (2.2 equiv.), pyridine, $0{ }^{\circ} \mathrm{C}, 2 \mathrm{~h}(92 \%)$; (d) 9 (1.0 equiv.), $\mathrm{Pd}\left(\mathrm{PPh}_{3}\right)_{4}$ (2 mol \%), aq. $\mathrm{Na}_{2} \mathrm{CO}_{3}$, THF, reflux, 5 h (80\%); (e) 11 (2.0 equiv.), $\mathrm{Pd}\left(\mathrm{PPh}_{3}\right)_{4}(8 \mathrm{~mol} \%)$, aq. $\mathrm{Na}_{2} \mathrm{CO}_{3}$, THF, reflux, 20 h (90\%); (f) conc. HCl, MeOH, reflux, 2 h (93\%); (g) (1) 40\% aq. KOH-EtOH (1:1), reflux, $3 \mathrm{~h}$, (2) cat. $p$-TsOH, $\mathrm{CH}_{2} \mathrm{Cl}_{2}$, reflux, $1 \mathrm{~h}$ (77\%); (h) $\mathrm{Cu}_{2} \mathrm{O}$, quinoline, $220{ }^{\circ} \mathrm{C}, 10 \min (96 \%$ ); (i) $\mathrm{PhI}\left(\mathrm{OCOCF}_{3}\right)_{2}$ (1.2 equiv.), $\mathrm{BF}_{3} \mathrm{OEt}_{2}$ (2.4 equiv.), $\mathrm{CH}_{2} \mathrm{Cl}_{2},-40{ }^{\circ} \mathrm{C}, 1.5 \mathrm{~h}(95 \%)$; (j) DDQ (1.0 equiv.), $\mathrm{CH}_{2} \mathrm{Cl}_{2}$, reflux, 30 h (99\%); (k) $\mathrm{H}_{2}, 10 \%$ Pd-C (20 wt \%), AcOEt, r.t., 2 h (99\%); (l) $\mathrm{ClSO}_{3} \mathrm{CH}_{2} \mathrm{CCl}_{3}(2.0$ equiv.), DMAP (1.0 equiv.), $\mathrm{Et}_{3} \mathrm{~N}$ (2.0 equiv.), THF, r.t., $4 \mathrm{~h}(96 \%)$; (m) $\mathrm{BCl}_{3}\left(3.0\right.$ equiv.), $\mathrm{CH}_{2} \mathrm{Cl}_{2},-78{ }^{\circ} \mathrm{C}$, $0.5 \mathrm{~h}$, then $0{ }^{\circ} \mathrm{C}, 4 \mathrm{~h}(96 \%)$; (n) (1) $\mathrm{Zn}$ powder (2 equiv.), $\mathrm{HCO}_{2} \mathrm{NH}_{4}$ (6 equiv.), THF-MeOH (1:1), $4 \mathrm{~h}$, (2) Amberlite IRC-50 ( $\mathrm{Na}^{+}$form), $\mathrm{MeOH}$, (3) Sephadex $\mathrm{LH}-20, \mathrm{MeOH}-\mathrm{CH}_{2} \mathrm{Cl}_{2}$ (1:1) (80\%). 
The spectroscopic data of the synthetic $\mathbf{1}^{17}$ were shown to be identical with those reported for the natural product. ${ }^{4}$ It is noteworthy that the ${ }^{1} \mathrm{H}$ NMR absorptions of aromatic (H-5, 6, 7, 15, 16) and hydroxylic protons of $\mathbf{1}$ shift considerably depending on the concentration of the samples. ${ }^{17}$ The ${ }^{1} \mathrm{H}$ NMR data of the synthetic $\mathbf{1}$ obtained at the low concentration ( $1.0 \mathrm{mg}$ of $\mathbf{1}$ in $0.7 \mathrm{~mL}$ of DMSO- $d_{6}$ ) were found to be identical with those reported for the natural product.

In conclusion, we have achieved the first total synthesis of lamellarin $\alpha 20$-sulfate (1) in 14 steps from the commercially available 2-(3,4-dimethoxyphenyl)ethylamine (4) in excellent overall yield (24\%). This synthesis opens the way to produce diverse sulfated lamellarins, which enable us to undertake the structure-activity relationship studies on integrase-inhibiting and anti-HIV activities. Studies along this line are in progress in our laboratories.

\section{References}

1. For a review of HIV-1 integrase inhibitors, see: Maurin, C.; Bailly, F.; Cotelle, P. Curr. Med. Chem. 2003, 10, 1795-1810.

2. For reviews of lamellarin alkaloids, see: (a) Cironi, P.; Albericio, F.; Álvarez, M. Prog. Heterocycl. Chem. 2004, 16, 1-26; (b) Bailly, C. Curr Med. Chem. Anti-Canc. Agents 2004, 4, 363-378; (c) Handy, S. T.; Zhang, Y. Org. Prep. Proc. Int. 2005, 37, 411-445.

3. (a) Quesada, A. R.; Gravalos, M. D. G.; Puentes, J. L. F. Br. J. Cancer 1996, 74, 677-682; (b) Ishibashi, F.; Tanabe, S.; Oda, T.; Iwao, M. J. Nat. Prod. 2002, 65, 500-504; (c) Facompré, M.; Tardy, C.; Bal-Mahieu, C.; Colson, P.; Perez, C.; Manzanares, I.; Cuevas, C.; Bailly, C. Canser Res. 2003, 63, 7392-7399; (d) Tardy, C.; Facompré, M.; Laine, W.; Baldeyrou, B.; Gravalos, M. D. G.; Francesch, A.; Mateo, C.; Pastor, A.; Jiménez, J. A.; Manzanares, I.; Cuevas, C.; Bailly, C. Bioorg. Med. Chem. 2004, 12, 1697-1712; (e) Marco, E.; Laine, W.; Tardy, C.; Lansiaux, A.; Iwao, M.; Ishibashi, F.; Bailly, C.; Gago, F. J. Med. Chem. 2005, 48, 3796-3807. 4. Reddy, M. V. R.; Rao, M. R.; Rhodes, D.; Hansen, M. S. T.; Rubins, K.; Bushman, F. D.; Venkateswarlu, Y.; Faulkner, D. J. J. Med. Chem. 1999, 42, 1901-1907.

5. Ridley, C. P.; Reddy, M. V. R.; Rocha, G.; Bushman, F. D.; Faulkner, D. J. Bioorg. 
Med. Chem. 2002, 10, 3285-3290.

6. Banwell, M.; Flynn, B.; Hockless, D. Chem. Commun. 1997, 2259-2260.

7. Liu, Y.; Lien, I. F.; Ruttgaizer, S.; Dove, P.; Taylor, S. D. Org. Lett. 2004, 6, 209-212.

8. During the course of our synthesis of lamellarin $\alpha$ 20-sulfate (1), Fürstner completed the total synthesis of the marine alkaloid dictyodendrin B, in which Taylor's protocol was successfully used for the final sulfate formation, see: Fürstner, A.; Domostoj, M. M.; Scheiper, B. J. Am. Chem. Soc. 2005, 127, 11620-11621.

9. Iwao, M.; Takeuchi, T.; Fujikawa, N.; Fukuda, T.; Ishibashi, F. Tetrahedron Lett. 2003, 44, 4443-4446.

10. Fujikawa, N.; Ohta, T.; Yamaguchi, T.; Fukuda, T.; Ishibashi, F.; Iwao, M. Tetrahedron 2006, 62, 594-604..

11. Merz, A.; Schropp, R.; Dötterl, E. Synthesis 1995, 795-800.

12. Oh-e, T.; Miyaura, N.; Suzuki, A. J. Org. Chem. 1993, 58, 2201-2208.

13. The boronic acid $\mathbf{1 1}$ was prepared from $O$-benzylisovanillin in a similar manner as described for the synthesis of 4-isopropoxy-5-methoxy-2-methoxymethoxyphenylboronic acid. See reference 10.

14. Boger, D. L.: Soenen, D. R.; Boyce, C. W.; Hedrick, M. P.; Jin, Q. J. Org. Chem. 2000, 65, 2479-2483.

15. (a) Takada, T.; Arisawa, M.; Gyoten, M.; Hamada, R.; Tohma, H.; Kita, Y. J. Org. Chem. 1998, 63, 7698-7706; (b) Tohma, H.; Morioka, H.; Takizawa, S.; Arisawa,, M.; Kita, Y. Tetrahedron 2001, 57, 345-352; (c) Hamamoto, H.; Anilkumar, G.; Tohma, H.; Kita, Y. Chem. Eur. J. 2002, 8, 5377-5383.

16. (a) Sala, T.; Sargent, M. V. J. Chem. Soc. Perkin Trans. 1, 1979, 2593-2598; (b) Solladié, G.; Pasturel-Jacopé, Y.; Maignan, J. Tetrahedron 2003, 59, 3315-3321.

17. Lamellarin $\alpha$ 20-sulfate (1). Mp 263-269 ${ }^{\circ} \mathrm{C}$ (dec.) (sealed capillary) (lit. ${ }^{4} \mathrm{mp}$ 145-148 ${ }^{\circ} \mathrm{C}$ ); IR (KBr): 3448, 1695, 1487, 1419, 1272, 1223, 1167, 1048, $839 \mathrm{~cm}^{-1}$; ${ }^{1} \mathrm{H}$ NMR (400 MHz, $17 \mathrm{mg}$ of 1 in $0.7 \mathrm{~mL}$ of DMSO- $d_{6}$ ): $\delta 3.37(\mathrm{~s}, 3 \mathrm{H}), 3.37$ (s, $3 \mathrm{H}), 3.86(\mathrm{~s}, 3 \mathrm{H}), 3.87(\mathrm{~s}, 3 \mathrm{H}), 6.80(\mathrm{~s}, 1 \mathrm{H}), 6.94(\mathrm{dd}, J=2.0$ and $8.0 \mathrm{~Hz}, 1 \mathrm{H}), 7.05$ $(\mathrm{d}, J=2.0 \mathrm{~Hz}, 1 \mathrm{H}), 7.18(\mathrm{~s}, 1 \mathrm{H}), 7.19(\mathrm{~d}, J=8.0 \mathrm{~Hz}, 1 \mathrm{H}), 7.29(\mathrm{~d}, J=7.4 \mathrm{~Hz}, 1 \mathrm{H})$, $7.38(\mathrm{~s}, 1 \mathrm{H}), 7.57(\mathrm{~s}, 1 \mathrm{H}), 8.48$ (br s, 1H), 9.03 (d, J= $7.4 \mathrm{~Hz}, 1 \mathrm{H}) ;{ }^{1} \mathrm{H}$ NMR (400 $\mathrm{MHz}, 1.0 \mathrm{mg}$ of 1 in $0.7 \mathrm{~mL}$ of DMSO- $\left.d_{6}\right): \delta 3.38(\mathrm{~s}, 3 \mathrm{H}), 3.38(\mathrm{~s}, 3 \mathrm{H}), 3.87(\mathrm{~s}, 3 \mathrm{H})$, $3.89(\mathrm{~s}, 3 \mathrm{H}), 6.81(\mathrm{~s}, 1 \mathrm{H}), 7.03(\mathrm{~d}, J=2.0 \mathrm{~Hz}, 1 \mathrm{H}), 7.04(\mathrm{dd}, J=2.0$ and $8.0 \mathrm{~Hz}, 1 \mathrm{H})$, 
$7.21(\mathrm{~s}, 1 \mathrm{H}), 7.26$ (d, J= 8.0 Hz, 1H), 7.35 (d, J= $7.4 \mathrm{~Hz}, 1 \mathrm{H}), 7.44$ (s, 1H), 7.56 (s, 1H), 9.09 (d, J=7.4 Hz, 1H), 9.45 (br s, $1 \mathrm{H}) ;{ }^{13} \mathrm{C} \mathrm{NMR} \mathrm{(100} \mathrm{MHz,} 17 \mathrm{mg}$ of 1 in 0.7 $\mathrm{mL}$ of DMSO- $\left.d_{6}\right): \delta 54.36,54.96,55.48,55.97,104.63,105.64,106.80,108.00$, $108.66,111.13,111.40,112.70,113.42$, 118.00, 118.05, 121.36, 121.88, 124.09, 126.83, 127.80, 133.26, 143.00, 144.93, 146.48, 147.87, 147.99, 148.71, 149.71, 153.96. HRFABMS (positive ion mode) $m / z$. Calcd for $\mathrm{C}_{29} \mathrm{H}_{22} \mathrm{NNa}_{2} \mathrm{O}_{11} \mathrm{~S}$ $\left[(\mathrm{M}+\mathrm{Na})^{+}\right]:$638.0709. Found: 638.0710. HRFABMS (negative ion mode) $\mathrm{m} / \mathrm{z}$. Calcd for $\mathrm{C}_{29} \mathrm{H}_{22} \mathrm{NO}_{11} \mathrm{~S}\left[(\mathrm{M}-\mathrm{Na})^{-}\right]$: 592.0914. Found: 592.0913. 


\section{Graphical abstract}

The first total synthesis of lamellarin $\alpha$ 20-sulfate, a selective inhibitor of HIV-1 integrase

Tomohiro Yamaguchi, Tsutomu Fukuda, Fumito Ishibashi, and Masatomo Iwao*
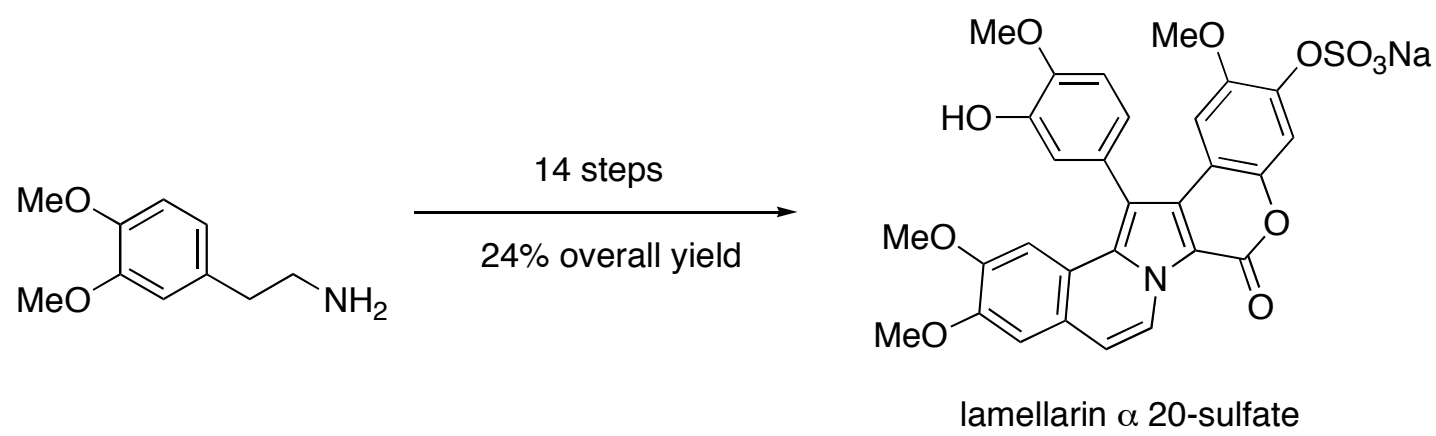